\title{
Solid Waste Disposal Habits of Students in Nigerian Universities: A Case of University of Uyo, Nigeria
}

\author{
Dr. Ekong E. Daniel *, Dr. Enefiok Ibok \\ Faculty of Social and Management Sciences Akwa Ibom State University Obio Akpa Campus Oruk Anam L. G. \\ A. Akwa Ibom State Nigeria \\ Department of Public Administration Faculty of Social and Management Sciences Akwa Ibom State University \\ Obio Akpa Campus Oruk Anam L. G. A. Akwa Ibom State Nigeria
}

\begin{abstract}
House to house inspection around the University of Uyo and environs revealed apparently poor sanitary situation. This unhealthy environmental situation was largely blamed on unwholesome waste disposal habits of the students living in the neighborhood. The aim of this study was to investigate waste disposal habits of the students of the University of Uyo. Methodology employed questionnaire, interview and observation techniques. The study area was divided into three zones. A total of Ninety randomly selected houses were sampled, thirty in each of the three zones. Seventy-one percent of the houses in the study area accommodated students of the University. The environments where students were accommodated were generally poor as a result of the indiscriminate waste disposal habits of the university students. The remaining 29\% that accommodated no student were judged above average. It is recommended that students irrespective of the course of study should be enlightened on environmental issues. Landlords must be encouraged to create circumstances that make for easy disposal of waste. Each home should have at least 3 different bins, properly labeled: waste to recycling; food wastes; wastes to dumping site. Home compost of leaves, grass clippings, and vegetable waste from kitchen is also recommended among others. The compost product can be added to vegetable garden and flower beds thereby reducing the need for artificial fertilizers and increasing garden productivity. Students in the university must be properly educated to take the lead in the course of environmental friendliness.
\end{abstract}

Key words: Solid waste, waste disposal, university students, habits, University of Uyo, Nigeria

\section{Introduction}

All organisms produce wastes, but none produces so much or of such diverse composition as humans. In the early history of mankind, there was no problem in the disposal of domestic waste. Each house was inhabited by a household of close family members and there was ample space for man to dispose of his waste. Moreover, household wastes at that time were generally of organic origin hence not damaging to the environment. Today with the rapid increase in populations, urbanization and industrialization the volume and diversity of wastes generated has increase in quantity and complexity. The increase and complexity has thus created a need to device appropriate waste disposal methods to ensure a clean and healthy environments (Chiras, 1985).

It may be generally assumed that students of higher institutions such as the University are enlightened and should champion environmental friendliness. Contrary to this assumption, house to house inspection round the University of Uyo and environs reveals an apparently poor sanitary situation. The aim of this study was to investigate waste disposal habits of the students of the University of Uyo living in the university and environs. Relevant measures were looked into as remedial measures to check the menace.

\section{Scope of the Study}

The waste of human societies comprises solid, liquid and gaseous wastes, but this study only concerns itself with solid wastes. According to Clarke quoted by Chiras (1985) "Solid wastes are only raw materials we are too stupid to use" the paper, glass, metals, tires, plastic that flow daily from the different homes to the surrounding bushes, streets and disposal sites represent a waste of valuable materials. Vegetable wastes from the kitchen enrich the soil while others could be recycled for more useful purposes. Putting it more politely, solid wastes at the household level are materials left over from consumption. At the public level, it is the material that leaves the household, which may be disposed formally or informally (Urban Age, Winter 1999). They include, paper, rubber, plastic, food waste, glass, textile, aluminium metals, leather, wood and others. Many factors interact to produce solid wastes. They include; large population, low products durability, an abundance of disposable items on the market, a lack of recycling, little product reuse, and a lack of individual commitment to reduce waste. Apparent abundant land for disposal is yet another factor. 


\section{The problem}

The University is a major feature in the landscape of the study area. It is therefore important to constantly assess its environmental impact on the neighbourhood. The routine monitoring of the University environs revealed a poor sanitary situation. This was largely blamed on unwholesome waste disposal habits of the students. If the assumption were true, it would negates the expectations that students of higher institutions are enlightened and should champion environmental friendliness. This study therefore investigated the waste disposal habits of the students in the study area to confirm their contribution to the environmental state of the university neighbourhood.

\section{Conceptualizing Solid Waste}

Waste generation is a normal and inevitable consequence of human activities. Wastes are either a byproduct of initial production processes or they arise when objects or materials are discarded after they have been used. According to the United States Environmental Protection Act of 1990, waste is defined as any substance which constitutes a scrap material or an effluent or unwanted surplus substance which requires to be disposed (Madu, 2004).

Oyediran (1997) sees waste as substances or objects discarded as worthless or unwanted, defective or of no further value from manufacturing or production processes. He noted further that the manner in which human settlements dispose of their wastes and even the degree to which they declare certain physical outputs of production and consumption processes to be waste, reflect level of development of the settlement.

Waste may be classified in terms of origin, physical form or physio-chemical properties. Explaining further, wastes may be described as solid, airborne particles or dust, liquids or effluent and gases. Some waste are toxic and hazardous. Toxic wastes refer to materials that can cause death or serious injury to humans or animals. Hazardous waste is a broader term referring to all wastes including toxic ones that pose an immediate or long term health risk or that endanger the environment (Fellman et al., 1995).

In Akwa Ibom State, Nigeria, the most important threat to urban environmental quality is solid waste from domestic and industrial activities. Domestic solid wastes are the by-products of house keeping activities and consumptions; they include fuel residues, wrapping papers and leaves, empty cans and containers. Industrial solid waste are generated in the course of manufacturing processes and include metal scraps, chips and grits from machinery shops, sawdusts, waste paper, pieces of glass etc (NEST, 1991).

Waste dumping is the common practice of waste disposal among students of University of Uyo. The waste are often dump indiscriminately on open plots of land and particularly on streets. This method is based on "throw away culture" in which wastes are disposed into the nearest open space, on land or surface water without environmental consideration. This is referred to as 'not in my backyard syndrome' whereby the waste is merely transferred from a location to another location where its nuisance value is perceived to be less. Sometimes, the wastes are buried or used in land field, with the hope that out of sight is out of mind (Opala, 1977).

It is pertinent to say that the heaps of solid wastes in Uyo Urban centre is not indicative of high level per capita consumption, this is attributed to a number of factors thus:

a) Rapid demographic expansion and population concentration in Uyo.

b) Rapid and uncontrolled expansion of the physical limits of the built up areas as a result of incorporation of outlying rural settlements, massive rural -urban migration, overcrowding, deprivation and grossly inadequate social welfare infrastructure and services.

c) Inherent operational inefficiencies and failure in connection with waste disposed haphazardly by urban residents in both authorized and unauthorized open dump sites most of which remain uncollected for months: and

d) Institutional, legislative and organizational lags, lapses and weaknesses in urban management and administration (CIDJAP, 1998).

\section{Methodology}

Methodology employed questionnaire, structured and unstructured interview and observation techniques. Simple random and purposive sample approach was adopted to select ninety households for the study. The study area was divided into 3 different zones (see figure 1). Thirty copies of questionnaire were administered in the same number of households in each zone. A total of ninety copies of questionnaire were administered in the ninety households selected for the study. However, a total of 84 copies were retrieved and used in the analysis.

\section{Findings and Discussion}

The study has revealed that students' population is significant in the study area. Seventy-one percent of the houses sampled accommodated students of the University. The environments of these houses were judged 
below average. The remaining $29 \%$ that accommodated no student were judged above average. The study thus revealed that the environment where students were accommodated were generally poor.

The highest percentage of waste generated in the university environs was food waste with $38 \%$ (see figure 2). Over forty-seven of these wastes were carelessly dumped in the surrounding farms and bushes (see Table 1), thereby damaging crops in the farms and causing land pollution. However, food wastes are of great economic value. They could be used as animal feeds. Paper was the second larges waste generated (35\%). Paper is a recyclable material and should not be thrown away; they should be collected into bags kept safe and dry for those who need them to buy.

Solid waste disposal problem in this area was further compounded by lack of public formal waste disposal system. There were no adequate designated public dumping sites; hence some inhabitants preferred burning of their solid wastes, while many resorted to dumping in the surrounding bushes, thus creating an unhealthy environment. Seventy-one percent of the sample confirmed lack of public solid waste disposal services. Public refuse disposal services in this area therefore became a matter of urgency.

Table: 1 Solid waste Disposal methods in the sampled Area

\begin{tabular}{|l|l|}
\hline Methods & Percentage of sample \\
\hline Waste disposal truck & $11.9 \%$ \\
Burning & $26.2 \%$ \\
Near by Bush & $47.6 \%$ \\
Dumping site & $9.5 \%$ \\
Others & $4.8 \%$ \\
\hline Total & $100 \%$ \\
\hline
\end{tabular}

Source: Author's field work (2011)

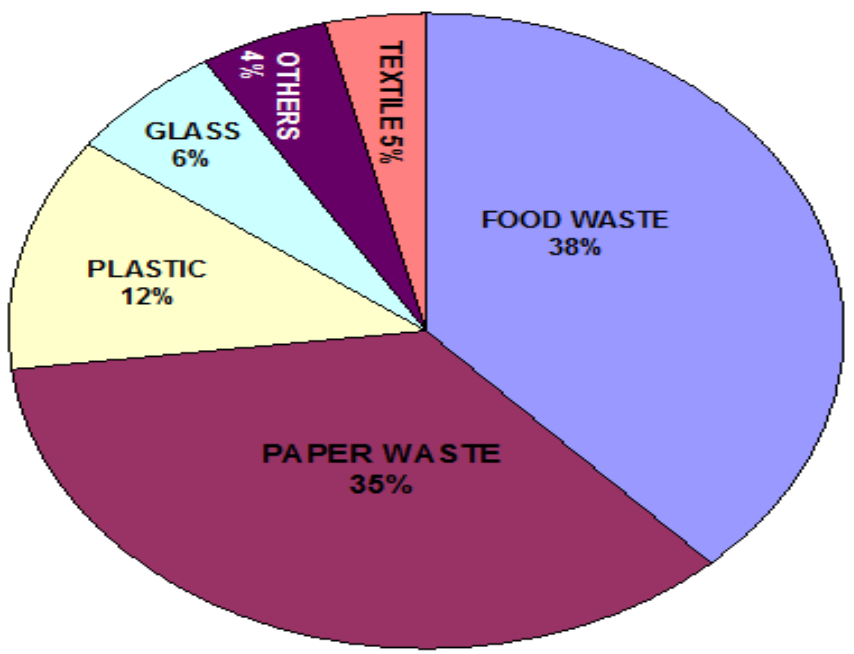

Fig. 2: Composition of Solid waste generated in the study region

University students show nonchalant attitude towards the routine environmental sanitation practices. On students waste disposal habits, $64 \%$ confirmed the uncooperative attitude of students to disposing of waste at the designated local sites. This was evident of poor waste disposal habits of the University students. The waste disposal habit of the student can be traced to values, culture and indigenous knowledge inculcated in them at the family level. Many of them lack hygiene education and training. It is not uncommon to see a student throw waste on the street, even into the drain channels meant to carry rain water. These practices constitute impediment to achieving healthy urban environments.

Moruff (2012) acknowledged that waste disposal is one important aspect of urban management crises in Nigeria. According to him, solid waste generated within the urban centres has become one of the most intractable problems of development in Nigeria. The poor waste disposal habits of our students therefore constitute crucial health and environmental problem facing the Nigerian urban centres. The students habit need be adjusted in order to achieve healthy urban environment in view of the fact that many Nigerian Universities are located in urban centres (Daniel \& Ituen, 2013).

Solid waste management in our urban centres requires multidimensional approaches. There are three general approaches to reduction of solid waste, namely:-

(1) Output Approach

(2) Through- put Approach

(3) Input Approach 
The Output Approach: This approach involves finding better ways of dumping solid wastes and of reducing the volume of waste. It takes a narrow look at solid waste as something to be discarded as cheaply and as safely as possible. Methods adopted by this approach include:

(i) Open dumping

(ii) Sanitary land filling

(iii) Composting

(iv) Incineration

Open Dumping: As the name implies, this is a method that wastes are dumped openly at designated sites. Sanitary Land filling: This is a method that solid wasted are dumped into a natural or artificial depression. They are compressed and daily covered with a layer of dirt. Composting: This is a process in which the organic wastes are allowed to undergo aerobic bacterial decay. Compost is used to build soil fertility. Incineration: This is a system where solid wastes are burned to generate electricity and steam heat for home and industries. Refuse incinerators reduce our dependency on non-renewable fuel, and help to reduce the amount of waste we throw away.

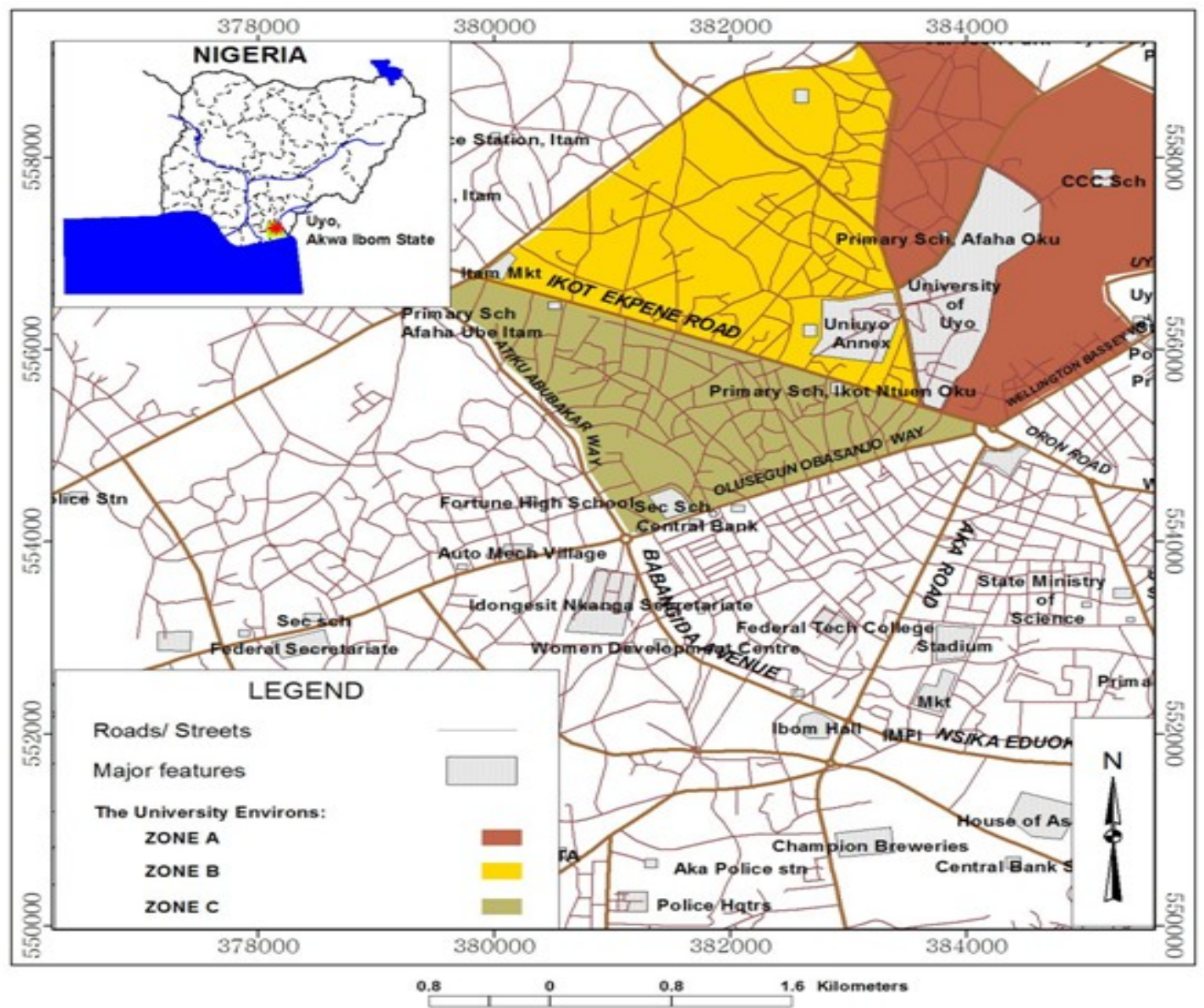

Fig. 1: The location of the University of Uyo and Environs

The Throughput Approach: This approach attempts to reduce solid waste production by reusing and recycling materials before they enter the solid waste stream. Reuse is simply the return of usable or repairable goods into the market system for someone to use. Packaging materials such as cardboard, boxes, bottles and grocery bags and what is commonly called "festac" bags can be reused by consumers, saving both energy and materials. Reusable beverage containers are well worth their slight extra cost. They can be sterilized, refilled and returned to the shelf. This cycle can be repeated over and over many times. Reuse reduces litter, it reduces the amount of material consumed by producers and helps reduce pollution and environmental disruption.

The Input Approach: Reductions in solid waste problems can also be achieved by an input approach. This approach attempts to, reduce the amount of materials in goods entering the consumption cycle. There are three ways of doing this namely: 
(i) Increasing product life span,

(ii) Reducing the amount of materials in goods and

(iii) Reducing Consumption.

\section{Conclusion}

Sanitation, water supply, electricity, security and telephone services are areas of critical concern in human settlements. Deficiencies in these services manifest themselves most obviously in the form of pollution, disease and economic stagnation. Students in higher institution and other enlightened persons should take the lead in promoting best sanitation practice to enhance environmental friendliness. We have the possibilities for informal recycling or disposal of the refuse we generate at home for better home environment. Persistent habit of indiscriminate disposal of solid wastes should be reported to the sanitation enforcement agencies who must take appropriate disciplinary measures against defaulters.

\section{Recommendations}

Students irrespective of the course of study should be educated on environmental issues. The basis for a clean earth is keeping our individual immediate environment clean. Landlords must be encouraged to create circumstances that make for easy disposal of waste. A situation where $67 \%$ of the houses sampled lacks refuse bin was quite unhealthy. Lack of waste bin encourages indiscriminate waste disposal habits. Waste bins should be provided for the different categories of wastes. Each home should have at least 3 different bins, properly labeled:

(1) Waste to recycling

(2) Food wastes

(3) Wastes to dumping site.

Composting can be practiced successfully at home. Individual homes can make their own compost piles of leaves, grass clippings, and vegetable waste from kitchen. The product can be added to vegetable gardens and flower beds. Simply burying organic waste in garden may also work well reducing the need for artificial fertilizers and increasing garden productivity. Pig farms are recommended at the periphery of the area to make use of the food wastes.

\section{References}

[1]. Adekunle, U. A. (1990) "Current Status of Water Supply and Sewage Disposal in the Urban and Rural Centres in Nigeria" in Onajude, M. O. eta al (eds) Revitalising the Urban and Rural Centres of Nigeria. Ile- Ife. L.G. Studies.

[2]. Catholic Institute for Development. Justice and Peace (CIDJAP) (1998). Sustainable improvements in Agricultural production and urban sanitation through Municipal solid waste recycling. Project proposal for Bread for the World. Germany: Bret Fiir Die Welt.

[3]. Chiras, D. D. (1985) Environmental Science: A framework for Decision Making. U.S.A. Benjamin/Cumings.

[4]. Daniel, E. and Ituen, U. (2013). Inter-Urban Trip Generation Models for the Urban Centres in Akwa Ibom State, Nigeria. Civil and Environmental Research, vol. 3, no. 4: pp. 55-62.

[5]. Fellman, H. J., Getis, A and Getis , J. (1995) Human Geography: Landscapes of Human Activities. Chicago: WMC Brown Publishers.

[6]. Goldstein, J. (1979) Recycling: How to Re-use Waste in Home, industry and Society. New York: Schocken Books, Informative and Practical Guides.

[7]. Madu, I. A. (2004). Urban solid waste problems in Nigeria. In: Ezenni, E. and Olekwa, N. N. (eds) Issues in Urbanization and Urban Administration in Nigeria, Enugu; Jamoi Enterprises (Nig.) pp. 100-126.

[8]. Moruff, Mudasiru (2012). Cultural Understanding of Space and Waste Disposal Habit Among the Urban Populace in Ibadan Metropolis, South Western Nigeria. Journal of Sustainable Development in Africa, vol. 14, no. 4: pp. 82-95

[9]. Nigerian Environmental Study/ Action Team (NEST) (1991). Nigeria's Threatened Environment: A National profile, Nest, Ibadan.

[10]. Okpala, J.(1997). "Problems of Solid Household Waste Disposal in Nigeira; Sorting at Source as Starting Point for Solution." In: Okwi, D. K. and Igbozuriki, U. M. (eds) Perspective in Environmental Movement. NEST Ibadan, pp. $101-112$.

[11]. Oyediran, A. S. (1997). "Waste generation and Disposal in Nigeria". In: Ezenni, E. and Elekwa, N. N. (eds) Issues in Urbanization and Urban Administration in Nigeria. Enugu: James Enterprises (Nig.), pp. 10 - 21.

[12]. Pollution- Who Causes It? (1980, May 8) Awake, pp. $4-5$.

[13]. What cities do with their waste? (1990, winter) Urban Age, vol. 6, no. 3, pp.32 -33. 